\title{
CHRISTMAS DISEASE
}

\author{
Rosemary Biggs, M.D., B.Sc., Ph.D. and R. G. Macfarlane, M.A., M.D., F.R.C.P., F.R.S. \\ Blood Coagulation Research Unit, Churchill Hospital, Oxford
}

Christmas disease is a hæmorrhagic state mainly affecting males, which was not distinguished from hæmophilia until 1952, when it was shown by Aggeler, White, Glendening, Page, Leake and Bates (1952) and Biggs, Douglas, Macfarlane, Dacie, Pitney, Merskey and O'Brien (1952) that the two conditions were due to fundamentally different defects in the blood-clotting mechanism. To appreciate the significance of the distinction it is necessary to understand the nature of the prothrombin-converting system of the blood, on which normal coagulation depends. In normal blood most of the prothrombin disappears during clotting because it is converted to thrombin, which is subsequently inactivated by antithrombin. Consequently serum, examined one hour after normal blood has clotted in a glass tube, contains very little prothrombin. In both hæmophilia and Christmas disease serum examined in this way by the 'prothrombin consumption test' is found to contain large amounts of prothrombin, demonstrating a failure of the prothrombin-converting mechanism. In severe cases of either condition the coagulation time in glass tubes is also prolonged. The defects in the two conditions are thus far the same, and distinction can only be achieved by tests which reveal the prothrombinconverting system in greater detail. These have shown that the two diseases are caused by the lack of two different components required for the formation of a prothrombin activator in the blood (Biggs, Douglas and Macfarlane, 1953). Accurate diagnosis and the development of specific assay procedures for these two components which form the basis of modern therapy depend on an understanding of this system.

The factors concerned in the normal formation of prothrombin activator can be studied by the 'thromboplastin generation test' devised by Biggs and Douglas (1953). It was found (Biggs, Douglas and Macfarlane, 1953) that a mixture of normal plasma treated with $\mathrm{Al}(\mathrm{OH})_{3}$, normal serum, platelets and $\mathrm{CaCl}_{2}$ produces a substance which will greatly accelerate the clotting of plasma (substrate) in the presence of $\mathrm{CaCl}_{2}$. The $\mathrm{Al}(\mathrm{OH})_{3}$ treated plasma does not contain prothrombin because this is removed by the $\mathrm{Al}(\mathrm{OH})_{3}$ treatment. Neither is there any appreciable amount of prothrombin in the normal serum. Thus the greatly accelerated clotting of the substrate cannot be due to thrombin, and must be due to rapid conversion of the prothrombin which it contains. The test, which is now usually carried out replacing platelets by some form of phospholipid, gives a direct record of ability to form a prothrombinconverting substance. It is found that if $\mathrm{Al}(\mathrm{OH})_{3}$ treated plasma from a hæmophilic patient is used to replace the normal treated plasma poor results (indicated by long substrate clotting times) are obtained, whereas the $\mathrm{Al}(\mathrm{OH})_{3}$-treated plasma of a Christmas disease patient behaves normally in this test. Reversely, if the serum component is derived from a patient with Christmas disease abnormal results are obtained, whereas serum from a hæmophilic patient behaves normally. Results illustrating this difference are given in

TABLe I

The Results of the Thromboplastin Generation Test in Specimens from Patients with Hamophilia and Christmas Disease

\begin{tabular}{|c|c|c|c|c|c|c|c|c|c|c|}
\hline \multirow{2}{*}{\multicolumn{2}{|c|}{ Condition Tested }} & & \multicolumn{3}{|c|}{ Source of Reagents } & \multicolumn{5}{|c|}{$\begin{array}{l}\text { Substrate Clotting Times (secs.) } \\
\text { After Incubation for: }\end{array}$} \\
\hline & & & $\begin{array}{l}\mathrm{Al}(\mathrm{OH})_{3} \\
\text { Plasma }\end{array}$ & Serum & Platelets & $\mathbf{I}$ & 2 & 3 & 4 & 6 mins. \\
\hline Normal & . & . & Normal & Normal & Normal & 77 & 60 & 27 & I I & I I secs. \\
\hline Hæmophilia & . & . & $\begin{array}{l}\text { Patient } \\
\text { Normal }\end{array}$ & $\begin{array}{l}\text { Normal } \\
\text { Patient }\end{array}$ & $\begin{array}{l}\text { Normal } \\
\text { Normal }\end{array}$ & $\begin{array}{l}70 \\
31\end{array}$ & $\begin{array}{l}62 \\
17\end{array}$ & $\begin{array}{l}65 \\
12\end{array}$ & $\begin{array}{l}61 \\
12\end{array}$ & $\begin{array}{l}48 \\
12\end{array}$ \\
\hline Christmas di & ease & . & $\begin{array}{l}\text { Patient } \\
\text { Normal }\end{array}$ & $\begin{array}{l}\text { Normal } \\
\text { Patient }\end{array}$ & $\begin{array}{l}\text { Normal } \\
\text { Normal }\end{array}$ & $\begin{array}{l}70 \\
65\end{array}$ & $\begin{array}{l}54 \\
45\end{array}$ & $\begin{array}{l}30 \\
36 \\
\end{array}$ & $\begin{array}{l}\text { I5 } \\
39\end{array}$ & $\begin{array}{l}10 \\
36\end{array}$ \\
\hline
\end{tabular}


Table 1 . In the top line are the results from wholly normal reagents. It will be seen that after four minutes' incubation of $\mathrm{Al}(\mathrm{OH})_{3}$-treated plasma, serum, platelets and $\mathrm{CaCl}_{2}$ a substance is formed which will clot the substrate plasma in I I seconds. This very short clotting time indicates the presence of a powerful prothrombin-converting substance. It will be seen that much longer clotting times occur in the defective systems.

To summarize, it will be seen that in both hæmophilia and Christmas disease there are defects in the formation of a prothrombin-converting substance, but the use of the thromboplastin generation test shows that the defects are different. It is now necessary to relate this information to the theory of blood coagulation. According to the old classical theory, prothrombin is converted to thrombin in the presence of $\mathrm{CaCl}_{2}$ by a factor called thromboplastin:

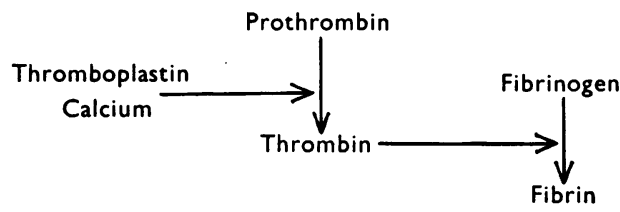

Thromboplastin in the classical theory was derived from tissue and was considered to be a direct activator of prothrombin. When the work on the thromboplastin generation test was done, it was thought that the $\mathrm{Al}(\mathrm{OH})_{3}$-treated plasma, serum and platelet components reacted together to form a substance very like tissue thromboplastin but differing in its origin, and it was therefore called plasma thromboplastin. Since this time the theory has become very complex and it is now clear that this name is misleading. A new theory might resemble that given in the scheme below.

It will be seen that the tissue factor and the direct conversion of prothrombin to thrombin are now separated by a chain of reactions and it is probably better to use the term 'prothrombin activator' for the direct activator of prothrombin.

Examination of this scheme reveals many factors, not visualised by the classical theory, including factors VIII and IX. Factor VIII (antihæmophilic globulin) which is present in normal $\mathrm{Al}(\mathrm{OH})_{3}$-treated plasma is the substance lacking from hæmophilic blood and factor IX (Christmas factor, plasma thromboplastin component) which is present in normal serum is lacking from the blood of patients with Christmas disease. The reaction of the two in the same phase of the clotting process probably accounts for the similar nature of the hæmostatic defects in the two conditions.

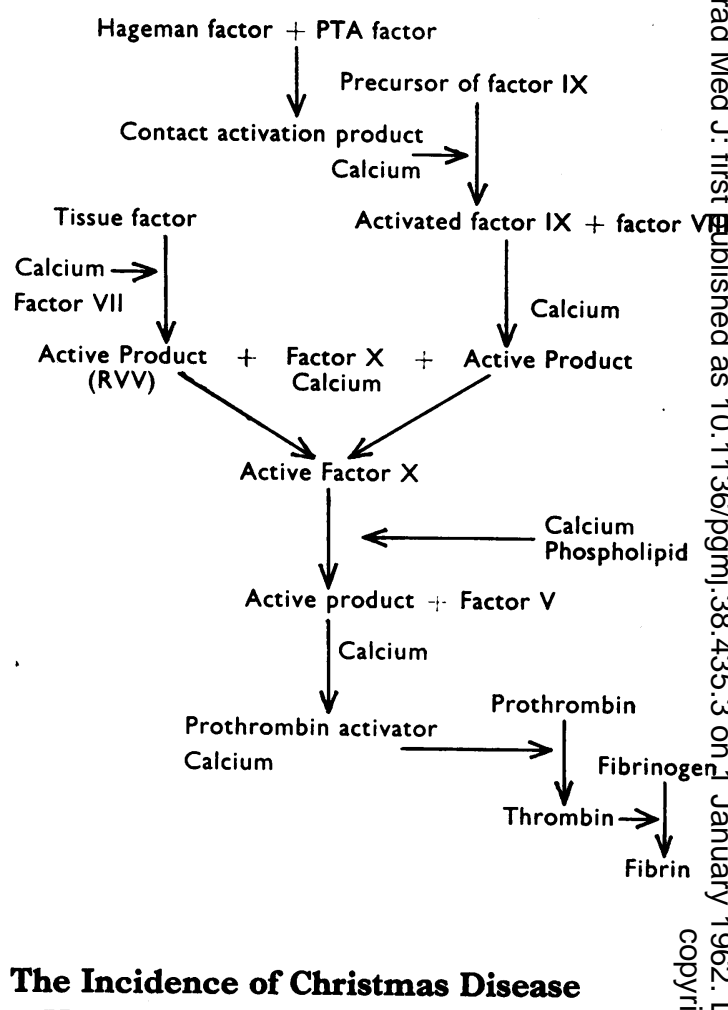

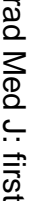

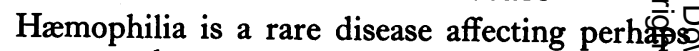
I or 2 people per 100,000 of the population. In England, Christmas disease is even more un common, there being about ro patients with hæmophilia to every patient with Christmas disease. The distribution of the disease in different $\vec{B}$ parts of the world and even within one country is 3 not uniform. In Switzerland for example Christ mas disease is proportionally more common, with about one case of Christmas disease for every three of hæmophilia. Again in a small region in England including Bristol, Cirencester and Swindon, thereare 16 families with Christmas disease, many of them being very mildly affected. This number of families is much greater than would be expected from the population of the area, and probably? indicates a common ancestry for the patients $\frac{D}{0}$ locally accumulated. In the Cirencester area it was possible to connect three of the families and, if the records before 1800 could have been traced, more relationships might have been found. (Simpson and Biggs, 1962.) The evidence of geographical ${ }^{\omega}$ distribution might well be helpful in assessing the mutation rate in these rare conditions.

\section{The Inheritance of Christmas Disease}

Christmas disease, like classical hæmophilia, is ${ }^{\circ}$ inherited as a sex-linked recessive characteristic. $\vec{D}$ The mode of inheritance is illustrated by the 
family tree which records the largest family in the Bristol area (Fig. I). The characteristics of this form of inheritance are that the children of an affected male are all apparently normal but all of his daughters are carriers and would be expected to transmit the disease to $50 \%$ of their sons. The female carrier married to a normal male should transmit the disease to $50 \%$ of her sons and $50 \%$ of her daughters should carry the abnormal gene.

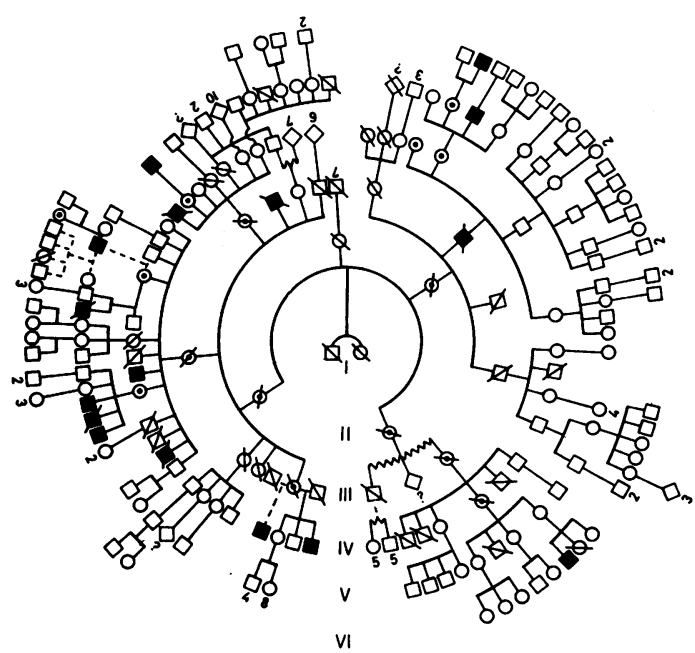

FIG. I.-Family tree of Christmas disease. Affected males are marked black. Deceased members are indicated by a diagonal line. Female carriers of Christmas disease are shown by a central dot. Diamond-shaped symbols indicate lack of information about the sex of offspring. Zigzag lines indicate lack of information about the family. Dotted lines indicate a second marriage. The different generations of the family are shown as Roman numerals.
Thus $50 \%$ of the sisters of an affected patient, who derived the disease from his mother, should transmit the disease in turn to $25 \%$ of the total male offspring. As with hæmophilia a proportion of the patients have a negative family history. In these cases either the disease is due to a mutation or to the transmission of the gene through several generations of female carriers. Of the $4 \mathrm{I}$ Christmas disease families known to us 13 have an apparently negative family history. Of these $4 \mathrm{I}$ families 24 have mildly affected members. This is a much higher proportion of mildly affected persons than is usual with hæmophilia, where the majority of patients are severely affected. The degree of severity is constant within a family. The high proportion of mildly affected individuals does not mean that Christmas disease is a less dangerous disease than hæmophilia; the patient with severe Christmas disease is just as badly disabled as the most crippled hæmophilic patient.

In determining the mutation rate in this type of condition the early death of many of the affected members and the relative infrequency of their offspring are naturally taken into account. These factors would cause the disease to die out unless fairly frequent mutations were to occur, but several studies suggest that other factors tend to perpetuate the disease. For example, in a study of the enormous Tenna valley family in Switzerland it seems that the female carriers of Christmas disease are more fertile than normal females and in two other studies the sisters of Christmas disease patients seem to have more than the expected number of affected sons (see Table 2). This might be caused by an excess of female carriers among the daughters of Christmas disease carriers or due

TABLE 2

Segregation of Sex and Christmas Disease from Sisters and Daughters of Christmas Disease Patients

\begin{tabular}{|c|c|c|c|c|c|}
\hline \multirow{3}{*}{ Sample } & \multirow{3}{*}{ Mothers } & \multicolumn{3}{|c|}{ Offspring } & \multirow{3}{*}{ Total } \\
\hline & & \multicolumn{2}{|c|}{ Male } & \multirow[t]{2}{*}{ Female } & \\
\hline & & Affected & $\begin{array}{c}\text { Un- } \\
\text { affected }\end{array}$ & & \\
\hline \multirow{2}{*}{$\begin{array}{l}\text { Oxford } \\
\text { Simpson \& Biggs (1962) }\end{array}$} & $\begin{array}{l}\text { Sisters of } \\
\text { C.D. patients }\end{array}$ & $25^{*}$ & 44 & 71 & 140 \\
\hline & $\begin{array}{l}\text { Daughters of } \\
\text { C.D. patients }\end{array}$ & 21 & 22 & 49 & 92 \\
\hline \multirow{2}{*}{$\begin{array}{l}\text { Pittsburgh } \\
\text { Lewis and } \mathrm{Li} \text { (1958) }\end{array}$} & $\begin{array}{l}\text { Sisters of } \\
\text { C.D. patients }\end{array}$ & 12 & 25 & 39 & 76 \\
\hline & $\begin{array}{l}\text { Daughters of } \\
\text { C.D. patients }\end{array}$ & 22 & 27 & 25 & $74^{\circ}$ \\
\hline
\end{tabular}

* Significantly different from expected one-quarter affected $\left(\chi^{2}=4.06\right.$ for one degree of freedom, $0.05>\mathrm{P}>0.02$ ). 
to an undue proportion of affected sons among the offspring of carriers. Since there is not an excess of affected males in the offspring of the daughters of Christmas disease patients, all of whom are carriers, the former explanation seems the more probable.

\section{The Female Carriers of Christmas Disease}

In hæmophilic families it is very unusual for the female carriers to have a greatly reduced blood level of factor VIII. Of I 4 females from Christmas disease families examined in Oxford, five had levels below $15 \%$ and in 23 the level was below $40 \%$. Of the 56 definitely proved carriers studied, $25 \%$ had low levels of Christmas factor. Similar findings in smaller series are reported by Lewis and $\mathrm{Li}$ (1958) and Barrow, Bulloch and Graham (1960). It therefore appears that the Christmas disease gene is less completely recessive than is that controlling hæmophilia.

\section{Symptoms of Christmas Disease}

The symptoms of Christmas disease are exactly the same as those of hæmophilia. The severely affected patient has multiple episodes of hæmarthrosis with residual joint deformity, massive hæmatomata which often affect muscles as well as various other episodes of bleeding, including hæmaturia, epistaxis, gastrointestinal bleeding and retroperitoneal bleeding. The mildly affected patient bleeds excessively only following trauma and in the majority of patients the disease is disclosed by serious bleeding after accidents, dental extraction or some other operative procedure. In our experience the mildly affected patient usually bleeds for three to 14 days after dental extraction and the bleeding is not controlled by pressure or suturing. This history distinguishes the type of bleeding from that of the common variety associated with mild capillary defects where bleeding is almost always stopped by pressure or suturing.

\section{The Assay of Christmas Factor}

On the theory that Christmas disease is a deficiency state caused by a lack of factor IX, therapy depends on the production and use of factor IX in a concentrated form. To achieve this it is imperative to have some more or less reliable method for the assay of factor IX which will not be affected seriously by any other irrelevant substance.

The preliminary discussion on the theory of blood coagulation mentioned a number of crude tests of clotting function and gave a complicated hypothesis of the interactions of the various factors concerned. This theory is pieced together from different fragments of more or less indirect evidence derived from empirical clotting testsฉ To devise a method of assay of an individuak factor based on this unsure theoretical foundation is by no means easy. The normal action of a factofis usually defined by the effects of its lack in $a$ particular class of patient and quantitative tests are therefore usually based on the ability of at sample to correct the clotting defect in a patient said to have the abnormality. In practice the्ల assay of Christmas factor is carried out by making? mixtures of a Christmas disease sample with thes sample to be tested and assessing the degree of 5 correction by one of the empirical tests using some standard of normality.

There are a number of grave difficulties ing applying such methods to the assay of Christmas factor. For example, if the degree of correction of the Christmas disease abnormality is assesse by the clotting time test or some modification of it the results may be influenced by reactions othe than those involving Christmas factor. This can best be explained using a diagram. In the clotting time test a certain time elapses in the normal

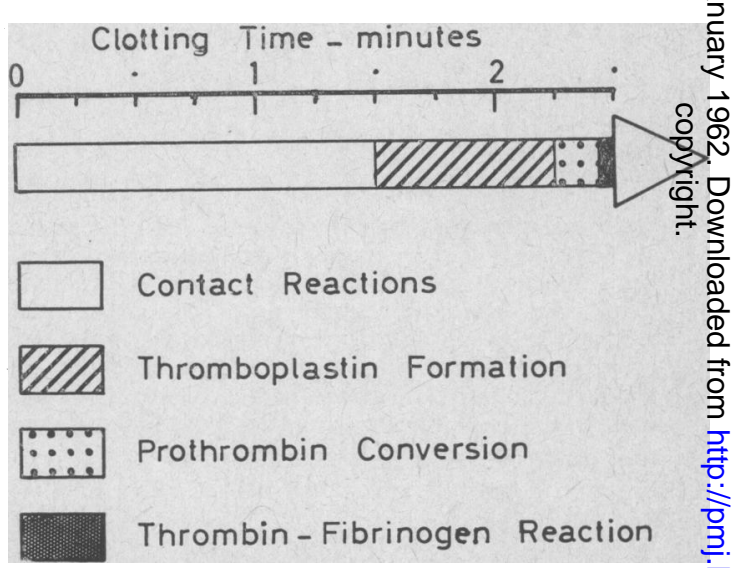

FIG. 2.-Diagram representing clotting as a series of consecutive phases of reactions.

sample before clotting occurs, and this time is presumably occupied by all the reactions outlined in the scheme on $\mathrm{p}$. 4 . In the diagram this time is represented by an arrow. The reactions can be divided into separate but overlapping phases, the first phase including those reactions stimulated by contact with a foreign surface. This is probably the most time-consuming phase of all ${ }_{\sigma}^{\omega}$ This is followed by the formation of prothrombin activator and in turn by the conversion of pro thrombin to thrombin. Of these phases, Christmas factor probably affects only the second, that con:cerned with the formation of prothrombin activator. Yet the most time-consuming phase is that associated with changes brought about by surface 
contact. Thus any test for Christmas factor based on the clotting time or any of its modifications, such as the calcium clotting time, the partial thromboplastin time, etc., will all be much affected by alterations in the contact phase of clotting. In practice this phase of clotting is very difficult and on occasion impossible to control.

The presence of prothrombin or thrombin may interfere with the assay of Christmas factor. The prothrombin-consumption test could be used to assess the amount of prothrombin activator formed in a system provided the amount of prothrombin in the original samples is comparable. But when a Christmas disease patient has been treated with concentrated Christmas factor the amount of prothrombin in the blood may be greatly raised and the results of this test become meaningless.

Another difficulty in the assay of Christmas factor is the choice of a standard of comparison. Normal samples vary considerably in their Christmas factor content and the random selection of a single normal is quite unsatisfactory. A final difficulty arises from the fact that Christmas factor as it occurs in the plasma is in an inactive state and must be activated before its potency can be assessed.

In trying to devise a method for the assay of Christmas factor we encountered these difficulties and the method that was finally evolved takes most of them into account. The thromboplastingeneration test is not affected by the contact phase of clotting, so this test was selected as the basis for comparison, the serum component being replaced by the test sample. The precursor of the Christmas factor is relatively stable on storage at $-20^{\circ} \mathrm{C}$., so a pool of many normal plasma samples was used as a standard. Serum for testing was derived by a standard method from plasma, so arranged that prothrombin was consumed during clotting in all samples. The process of clotting also activates the Christmas factor from the precursor state. The method is well adapted to the testing of concentrated therapeutic material which can be added to Christmas disease plasma and the mixture clotted to provide the test serum. The method is described in detail by Biggs, Bidwell, Handley, Macfarlane, Trueta, Elliot-Smith, Dike and Ash (1961) and Biggs and Macfarlane (1962).

All the coagulation tests must be assessed against the only criterion of their practical efficiency, namely, their usefulness in the study of patients, and it is still not entirely clear if this criterion will validate this assay method. Using the method, nearly all patients who are severely affected have $\circ \%$ of Christmas factor in their blood. Mildly affected patients have levels between $\circ$ and $15 \%$. Patients with levels demonstrably above $\circ \%$ are nearly all mildly affected. There is some variation in severity between patients whose blood level appears to be $o$, some being more severely affected than others. This may be because Christmas factor levels between 0 and $2 \%$ are not easy to distinguish from $0 \%$ and the possession of 1 or $2 \%$ of Christmas factor may make much difference to the clinical expression of the disease.

\section{Therapeutic Materials}

The treatment of hæmorrhage in patients with Christmas disease consists in attempting to replace the missing coagulation factor. This may be achieved using whole blood, plasma or concentrated Christmas factor. The extent to which each of these is effective will depend almost entirely on its ability to raise the blood level of Christmas factor. This ability is less than would be expected from calculations of simple replacement. For example, $\mathrm{I}, 000 \mathrm{ml}$. of plasma of activity $100 \%$ given to a patient of plasma volume of $2,000 \mathrm{ml}$. would be expected to raise the blood level to $33 \%$. This expectation depends on the assumption that none of the activity is lost from the circulation or destroyed in any way. In our experience it is unusual for such a dose of plasma to raise the blood level by more than Io to $15 \%$. The clinical response to plasma therapy is not usually very good and is quite consistent with the assumption that plasma levels achieved after such treatment are really lower than expected, and, since treatment with plasma is limited by the volume which can be transfused, the use of concentrated material may be the only effective method.

To prepare concentrated material from whole blood is very wasteful unless the other plasma fractions can be used. We thought of making Christmas factor from animal blood, but two considerations made us discard this plan. In the first place, severely affected patients with Christmas disease are much more infrequent than those with hæmophilia and it was thought that a sufficient supply might be obtained from human blood. The second consideration was that a fraction rich in Christmas factor activity is derived from a current large-scale human-plasma fractionation process. This fraction contains beta-globulins and lipoproteins and remains when other useful fractions, such as fibrinogen, albumin and gamma-globulins, have been removed and until now has had no practical use. This material is therefore available and is ideal as a starting point for a Christmas factor concentration process.

In England large-scale fractionation is carried out by the ether process of Kekwick, Mackay and Record (1946), and produces a final residue called $\mathrm{G}_{2}$ which contains much Christmas factor activity. Christmas factor, together with other clotting factors, notably prothrombin, factor $\mathrm{X}$ and 
probably factor VII, can be adsorbed on to $\mathrm{Ca}_{3}\left(\mathrm{PO}_{4}\right)_{2}$ and eluted therefrom with sodium citrate. The opalescent eluate is dialyzed and largely cleared of visible fat by the ether treatment of McFarlane (1942). The solution can then be filtered through a porcelain candle for sterilization. There are naturally difficulties in this process. At all stages the material contains much prothrombin and the final product usually contains 2,000 to 4,000 units of prothrombin per $\mathrm{ml}$. If even a trace of this prothrombin is converted to thrombin it causes intravascular clotting in test animals. At all stages, therefore, care must be taken to avoid the activation of prothrombin. Heparin and some citrate must be present from the elution stage. The final product must always be tested for thrombin activity before administration to a patient. A second difficulty may arise in the sterilization of the material by filtration. The opalescent solution before freezing with ether, filters only with great difficulty, probably because the filter pores become blocked with fat. After treatment with ether the filtration is much more rapid, but the effectiveness of this treatment varies and it is to be presumed that some unknown condition in the process or in the original samples controls the degree to which the undesirable fat is held in the solution.

The final therapeutic material is lyophil-dried and when reconstituted for use usually has 5 to 20 times the Christmas factor activity of normal serum and contains 2.000 to 4,000 units per ml. of prothrombin. The material probably also contains factors VII and X but these have not yet been studied.

\section{Properties of Christmas Factor}

Christmas factor is probably present in plasma as an inactive precursor which is activated during clotting. Its activity is usually tested in serum and this assay method is based on the assumption that no Christmas factor is used up in the process of coagulation. This assumption is supported by the fact that during the clotting of a sample known to contain only 5 or $10 \%$ Christmas factor activity, apparently no activity disappears; thus if any activity is utilised during clotting it is to be presumed that it is less than $5 \%$, which could not be detected by most testing systems.

Christmas factor activity is destroyed by heating to $56^{\circ} \mathrm{C}$. for 30 minutes, it is adsorbed onto $\mathrm{BaSO}_{4}, \mathrm{Al}(\mathrm{OH})_{3}, \mathrm{Ca}_{3}\left(\mathrm{PO}_{4}\right)_{2}$ etc. Electrophoretically the activity migrates with the betaglobulin.

\section{The Treatment of Hæmorrhage in Christmas Disease Patients}

The treatment of hæmorrhage in Christmas disease patients is, as has been said earlier, a question of raising the blood level of Christmas factor. The levels which have to be achieved i⿱⺈ order to be effective depend largely on the lesiop to be treated. Spontaneous bleeding such as tha? causing hæmarthroses, hæmatomata or hæmaturiâ. can often be treated satisfactorily by plasm疓 transfusion though this is not always successfu $\tilde{F}_{0}$ $\mathrm{I}, 000 \mathrm{ml}$. of plasma given to an adult patien usually raise the level of Christmas factor in the blood to about 10\% of normal. At this level tho mildly affected patient seldom has spontaneous bleeding and it seems that even such low levels produced therapeutically would be sufficient to prevent such bleeding in the severely affected patient.

Traumatic bleeding is different. Levels more than $30 \%$ are required to control traumatie. bleeding and these cannot be achieved witkw plasma transfusion. For example a mildly: affected patient who had a dental extraction oozed continuously for 21 days despite plasma trans fusion, his hæmoglobin fell to $52 \%$ and he re을 quired the transfusion of three pints of whole blood. The blood levels of Christmas factor were never above $10 \%$ of normal. This patient's progress is typical of our experience of the treat ment of Christmas disease with plasma trans fusion. The danger of relying on plasmaois emphasised by the report of a fatal case by Carter? Hougie and Menk (r960). Thus we think traumatic bleeding in Christmas disease patients can only be controlled safely by the use of con centrated material. The effectiveness of the material made in Oxford was illustrated for two cases by Biggs and others (196r). We can now $\vec{B}$ add experience with five more patients. One of these had a major surgical operation, four had dental extractions and one was treated mainly? because he was the type case of Christmas disease and it was naturally of interest to be certain that the material was effective in his case.

Case 1.-H., aged 56. The patient was a severely? affected bleeder with multiple joint deformity and $\mathbf{a}$ blood level of Christmas factor of $0 \%$. He had suffered? for many years from bleeding hæmorrhoids; these had been treated unsuccessfully by injection on manyo occasions and for the last two years he was becoming more and more incapacitated by chronic anæmia and required many transfusions. The patient was treated with a I4-day course of concentrated Christmas factor. $N$ On the fifth post-operative day two teeth were extractedN at the patient's own request because he was so astonished ${ }^{\omega}$ at his freedom from bleeding and was anxious to take advantage of the opportunity to dispose of two trouble some teeth. The post-operative course was uneventful. The levels of Christmas factor (factor IX) and prothrombin in his blood are shown in Fig. 3.

Case 2.-C., aged 35 , was a relatively mildly affected 0 patient who had nevertheless bled excessively in the past following dental extraction. Despite daily plasma transfusion he had bled intermittently for nearly three 

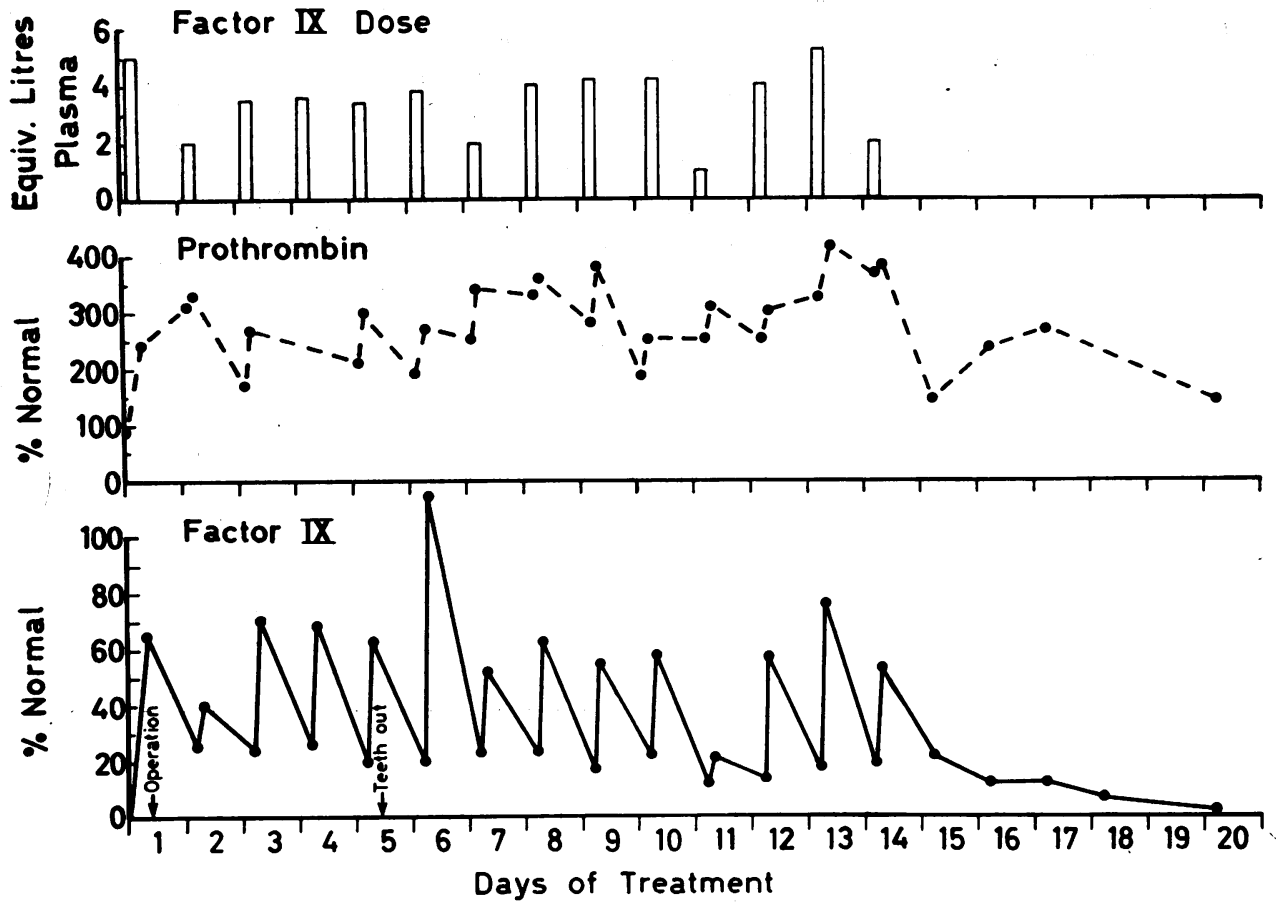

FIg. 3.-The levels of Prothombin and Factor IX in the blood of Case I during treatment with concentrated Christmas factor.

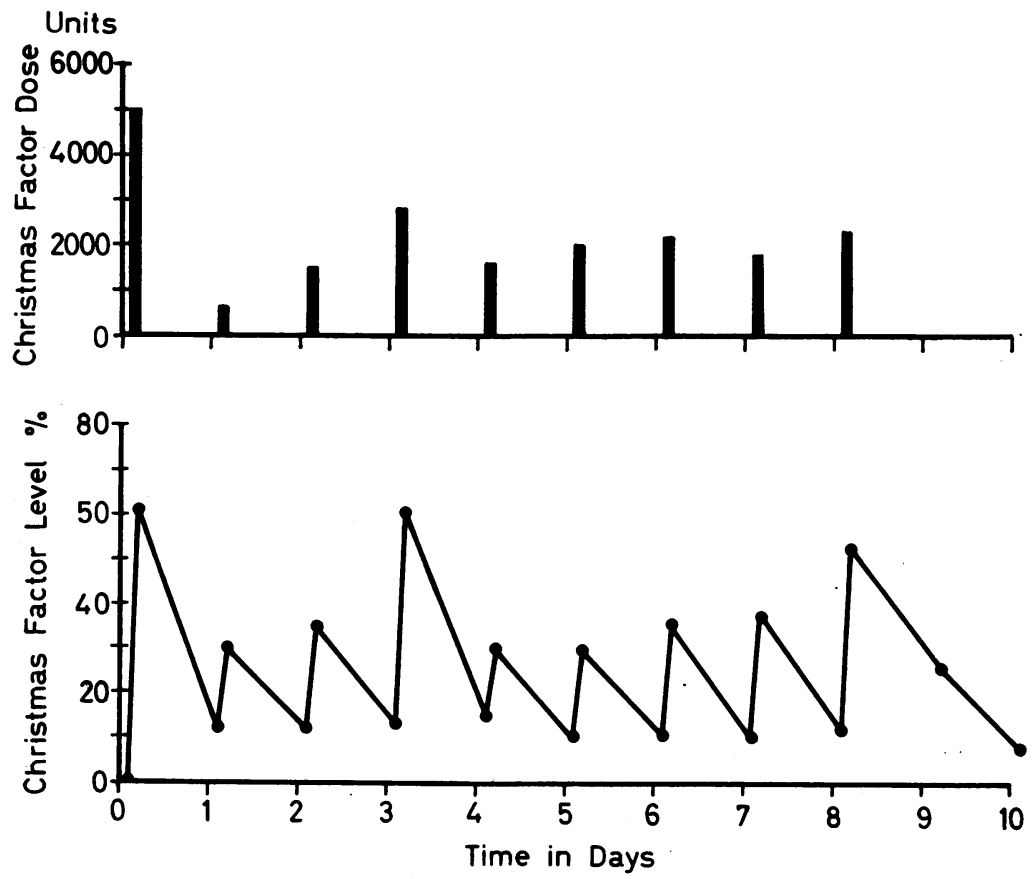

Fig. 4.-The levels of Christmas factor in the blood of Case 3 following treatment with concentrated Christmas factor. One unit of Christmas factor is equivalent to $\mathrm{I} \mathrm{ml}$. of average normal plasma. 
weeks following the extraction of seven teeth and required the transfusion of 7 pints of whole blood. He was given an eight-day course of Christmas factor concentrate and two teeth were removed entirely without bleeding.

Case 3.-F., aged 4I, was a severely affected patient with no detectable Christmas factor in his blood and with multiple previous episodes of hæmarthrosis. He had a total clearance of the remaining five teeth and stumps at one operation and was given nine daily injections of Christmas factor. The sockets were completely healed in 12 days. A record of his response to treatment is shown in Fig. 4 .

Case 4.-F., 4I-year-old patient who was clinically severely affected with disabled joints. The blood level of Christmas factor was $2 \%$. He had an eight-day course of Christmas factor concentrate and remaining eight teeth and four roots were removed at one operation. There was no bleeding.

Case 5.-Stephen Christmas, age 15 . The patient was admitted to hospital with an acute hæmarthrosis of the left knee. He was given two injections of Christmas factor and the knee improved rapidly. Later he was again admitted with hæmarthrosis and on this occasion was given doses of $1,000 \mathrm{ml}$. of plasma. The blood levels of Christmas factor after the concentrated material are shown in the chart in Fig. 5. After the plasma the level of Christmas factor was $6-8 \%$ of normal.

These patients together with those reported previously demonstrate beyond all reasonable

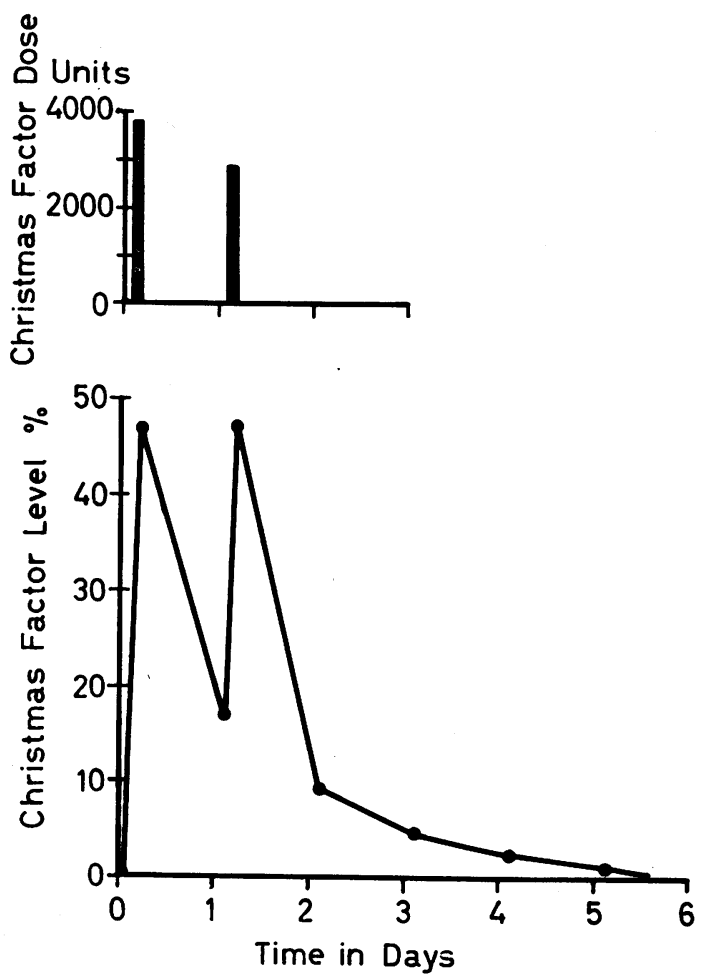

FIG. 5.-The levels of Christmas factor in the blood of Case 5 following treatment with concentrated Christmas factor. One $\mathrm{ml}$. of Christmas factor is equivalent to $\mathrm{I} \mathrm{ml}$. of average normal plasma. doubt that the concentrated material is effecti胥 in the control of traumatic bleeding even in the most severely-affected patients.

Some of the features of the treatment of these patients are of interest. The relation of the dose $\vec{g}$ material given and the response of the patient terms of rise in plasma level of Christmas factor for six patients are given in Tables 3 and 4 . The resu席

Table 3

The Dose of Christmas Factor Given to Case a Patient of Weight 73 Kg. and Estimated Plasma VOLUME OF 3,700 ML. (HIS HÆMOgLOBIN LEVEL W $\overrightarrow{A S}$ About $70 \%$ of Normal During Treatment og I 4 Consecutive Days)

\begin{tabular}{|c|c|c|c|c|}
\hline \multirow{2}{*}{$\begin{array}{l}\text { Day of } \\
\text { Treat- } \\
\text { ment }\end{array}$} & \multicolumn{2}{|c|}{ Dose } & \multicolumn{2}{|c|}{$\begin{array}{l}\text { Plasma Level of } \\
\text { Christmas Factor }\end{array}$} \\
\hline & $\begin{array}{l}\text { Volume } \\
\text { (ml.) }\end{array}$ & $\begin{array}{c}\text { Plasma } \\
\text { Equiva- } \\
\text { lent }\end{array}$ & $\begin{array}{c}\text { Rise in } \\
\text { Level } \\
(\%)\end{array}$ & $\begin{array}{l}\text { Rise } / 1,00 \mathcal{W} \\
\text { ml. of } \\
\text { Dose }(\%)\end{array}$ \\
\hline I & 250 & 5,000 & 62 & 12.4 \\
\hline 2 & 280 & 2,000 & I 5 & $7 \cdot 5$ \\
\hline 3 & 214 & 3,500 & 49 & 14.0 \\
\hline 4 & 210 & 3,600 & 46 & I 3.0 \\
\hline 5 & 183 & 3,406 & 43 & 13.0 \\
\hline 6 & 426 & 3,800 & 85 & 22.0 \\
\hline 7. & 223 & 2,000 & 30 & 15.00 \\
\hline 8 & 326 & $4, \infty 00$ & 40 & 10.08 \\
\hline 9 & 300 & 4,200 & 37 & $9.0 \leq$ \\
\hline 10 & I 98 & 4,200 & 36 & $8.5 \overline{0}$ \\
\hline I I & 200 & 1,000 & ro & 10.0 \\
\hline 12 & 200 & 4,000 & 34 & 8.5 \\
\hline I 3 & 200 & 5,200 & 59 & I 1.0 \\
\hline I4 & 190 & 2,000 & 35 & 17.5 \\
\hline Average & & & & 12.2 \\
\hline
\end{tabular}

The expected rise in Christmas factor for a patien of this weight given dose volumes of $2-400 \mathrm{ml}$. would vary from 25 to $27 \%$ per $1,000 \mathrm{ml}$. The averags observed rise $(12.2 \% / 1,000 \mathrm{ml}$.) is about $47 \%$ of this expected value.

for the first case of Biggs and others is omitte because the assay method had not been stabilized at the time that he was treated, and much tech nical difficulty was experienced in obtaining bloog samples from an unco-operative small child whose arm had been amputated. The results with this first case were of the same general pattern as the others. From Table 3 it will be seen that the rise in the level of Christmas factor for case I was less than would be expected from the size of the dose given. In Table 3 the results of one case are given in detail. In Table 4 the average observed rise if the level of Christmas factor per $1,000 \mathrm{ml}$. equil valent of the dose for five other patients is com@ pared with the expected rise calculated for the size of the patient. It will be seen that in all five cases the observed rise is only a small proportio $\vec{P}$ of that expected. This discrepancy might be du⿳亠⿴囗十 
TABLE 4

The Theoretical and Observed Rise IN THE LeVEL of Christmas Factor After the Infusion of Active Material

\begin{tabular}{|c|c|c|c|c|}
\hline & \multirow{2}{*}{ Patient } & & \multicolumn{2}{|c|}{$\begin{array}{l}\text { Rise in Level of Christmas } \\
\text { Factor } / 1,000 \mathrm{ml} \text {. Dose }\end{array}$} \\
\hline & & & $\begin{array}{c}\text { Average } \\
\text { Observed Rise }\end{array}$ & $\begin{array}{l}\text { Expected } \\
\text { Rise }\end{array}$ \\
\hline I & $\ldots$ & . & I6.4 & $35-40$ \\
\hline 2 & $\ldots$ & . & 12.4 & $30-33$ \\
\hline 3 & $\cdots$ & . & 12.2 & $25-27$ \\
\hline 4 & . & . & 10.6 & $40-44$ \\
\hline 5 & . & . & 13.0 & $32-37$ \\
\hline
\end{tabular}

to the loss of material into the tissues of the recipient, but this explanation seems unlikely because the discrepancy is about the same after all doses and does not decrease after the first one or two doses. If the loss were associated with a saturation of the tissues with Christmas factor this saturation must be complete at some stage and in Case $I$ it was certainly not complete after 14 days.

The loss of Christmas factor might be assumed to be due to some unidentified inhibitory factor. But the same deficient response occurred both in the mildly-affected patients whose blood contained I or $2 \%$ of Christmas factor and in those who were severely affected. It seems a little unlikely that the mildly-affected patients have inhibitors in their blood.

The apparent poor response could also be due to some artefact in the testing system which either underestimates the amount of the Christmas factor in the patient's blood or overestimates the activity of the therapeutic material. This possibility cannot be excluded but the poor response which occurs after plasma transfusion is well correlated with the equally poor clinical effect. Whatever the explanation the fact of the discrepancy must be noted; intractable facts should lead to new ideas.

Another feature of the treated patients already mentioned is the longer survival of Christmas factor in their blood as compared with the survival of AHG in cases of hæmophilia. In three of the five patients the level of Christmas factor 24 hours after its infusion was $50 \%$ of the immediate post infusion level. In hæmophilic patients the usual rate of loss of AHG from the circulation is $50 \%$ in 12 hours or less. In two patients with Christmas disease the rate of loss was also $50 \%$ in 12 hours. The two patients with the rapid loss were the most severely affected and the two with grossly prolonged clotting times.

Another feature of interest is the greatly raised level of prothrombin in these patients. It is usual for levels of 300 to $400 \%$ of normal to be achieved during the treatment period and these levels interfere seriously with the prothrombin consumption test, the results of which are no longer comparable to those of normal blood.

\section{Other Possible Therapeutic Uses for Christmas Factor Concentrate}

The concentrate used to treat these patients certainly contains large amounts of prothrombin and probably also factors VII and X. In liver disease some or all of these factors are much reduced, and if operation were proposed for a patient it seems very probable that this material would reduce hæmorrhage. For natural deficiencies of factors VII and X also it would be reasonable to suppose that this material would be effective. Larrieu, Caen, Soulier and Bernard (1955), have used a similar concentrate to treat the hæmostatic defect of liver disease with good results.

\section{Conclusion}

The original distinction of Christmas disease from hæmophilia was based on the different behaviour of blood samples from cases of the two conditions when tested in vitro under admittedly artificial conditions. The basis of these tests was the theory that normal clotting is dependent on the generation, by a series of complex reactions in the plasma, of a prothrombin activator. One of the factors involved in these reactions is Factor VIII, the deficiency of which is responsible for hæmophilia. There was good clinical evidence that the administration of plasma preparations which, by in vitro testing had a high Factor VIII content, brought about a temporary return of the patient's hæmostatic mechanism to normal. This clinical response was therefore confirmatory evidence that Factor VIII existed as a real entity and was not merely an artefact produced by plasma fractionation, or simply a component of artificial reactions in vitro which might not be relevant to the hæmostatic efficiency of coagulation in vivo.

The discovery of a natural defect in the formation of prothrombin activator, which was not due to Factor VIII deficiency led to the supposition that another factor must be normally involved, and that this factor (which was called Christmas factor and subsequently Factor IX) was deficient in Christmas disease. Despite the clearcut differences in the behaviour and properties of Factor VIII and Factor IX when examined in vitro, some doubts on the physiological reality of these differences persisted. The clinical and genetic similarity of hæmophilia and Christmas disease gave some grounds for suspicion that the 
properties ascribed to Factor IX might be, in some way, merely an aspect of Factor VIII when viewed under artificial conditions.

The findings described here are confirmatory evidence that Factor IX is a physiological entity. The preparation of human plasma fractions with high Factor IX activity was made possible by the use of assay methods based on the thromboplastin generation test, and the theory of a multi- factorial system required for the normal formation of a prothrombin activator. Preparations whicl had high activity when tested in vitro by these methods have given excellent results when givef. intravenously in cases of severe Christmas: disease undergoing surgery, and little doubt can now remain that Factor IX is a distinct ans necessary component of the normal clotting mechanism.

\section{REFERENCES}

Aggeler, P. M., White, S. G., Glendening, M. B., Page, E. W., Leake, T. B., and Bates, G. (I 952): Plasma Thrombo= plastin Component (PTC) Deficiency: A New Disease Resembling Hæmophilia, Proc. Soc. exp. Biol. (N.Y.) 79, 692 .

Barrow, E. M., Bulloch, W. R., and Graham, G. B. (1960): A Study of the Carrier State for Plasma Thromboc plastin Component (PTC, Christmas Factor) Deficiency Utilizing a New Assay Procedure, F. Lab. clin. Med.

Biggs, R., Douglas, A. S., Macfarlane, R. G., Dacif, J. V., Pitney, W. R., Merskey, C., and O’Brien, J. R. (i952) Christmas Disease: A Condition Previously Mistaken for Hæmophilia, Brit. med. F., ii, I378.

$\longrightarrow,-$ (1953): The Formation of Thromboplastin in Human Blood, F. Physiol. (Lond.), Irg, 89. and Macfarlane, R. G. (1962): 'Human Blood Coagulation and its Disorders'. Oxford: Blackwell Scientifi Publications.

, Bidwell, E., Handley, D. A., Macfarlane, R. G., Trueta, J., Elliot-Smith, A., Dike, G. W. R., and Ashō B. J. (196r): The Preparation and Assay of a Christmas Factor (Factor IX) Concentrate and its Use in the Treat=ment of Two Patients, Brit. F. Hamat., 7, 349.

Carter, S. D., Hougie, C., and Menk, K. (1960): Fatal Case of Congenital Plasma Thromboplastin Componen Deficiency, F. Amer. med. Ass., I73, 63 I.

Kakwick, R. A., Mackay, M. E., and Record, B. R. (1946): Fractionation of Human Plasma with Ether, Nature

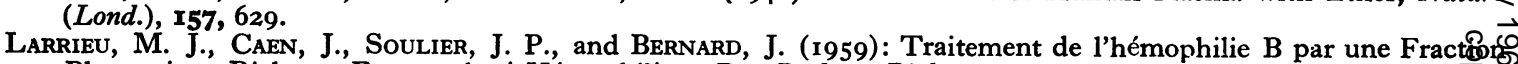
Plasmatique Riche en Facteur Anti-Hémophilique B. Path. et Biol., 7, 2507.

LewIS, J. H., and LI, C. C. (1958): Genetic Considerations in Hæmophilia A and B, Proc. Ioth Int. Congr. Genæt. $2,168$.

McFARLANE, A. S. (1942): Behaviour of Lipoids in Human Serum, Nature (Lond.), r49, 439.

Simpson, N. E., and BIgGs, R. (1962): The Inheritance of Christmas Factor, Brit. '尹. Hamat., 8 (in press). 